\title{
Decreased white blood cell counts in semiconductor manufacturing workers in Taiwan
}

\author{
J-C J Luo, L L Hsieh, M J W Chang, K-H Hsu
}

Occup Environ Med 2002;59:44-49

See end of article for authors' affiliations

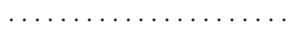

Correspondence to: Dr K-H Hsu, Laboratory for Epidemiology, Department of Health Care Management, Chang Gung University, Tao-Yuan, Taiwan;

jane@mail.cgu.edu.tw

Accepted 12 July 2001

\begin{abstract}
Objectives: To assess the systematic health effects on the liver, kidney, and haematological function tests of workers in semiconductors in Taiwan.

Methods: 926 workers of a semiconductor plant in Taiwan in July 1995 were investigated. Complete blood tests including liver, kidney, and haematological functions were available from 227 workers.

Results: There was a significantly lower mean (SD) white blood cell (WBC) count in male workers of photolithography $\left(5870(1190) / \mathrm{mm}^{3}, \mathrm{p}=0.003\right)$ and implantation $\left(6190(1150) / \mathrm{mm}^{3}, \mathrm{p}=0.018\right)$ than that of male control workers $\left(7350(1660) / \mathrm{mm}^{3}\right)$. There was a significantly higher prevalence of leukopenia in male photolithography workers $(6$ of $20 ; 30 \%)$ than in male control workers (1 of 18; $5.6 \%)$, the crude odds ratio (OR) was 7.3 (95\% confidence interval $(95 \% \mathrm{Cl}) 1$ to 55.6$)$, and the multivariate adjusted $\mathrm{OR}$ was $8.1(95 \% \mathrm{Cl} 0.83$ to 78.3$)$. The tests for serum glutamic oxaloacetic transaminase (SGOT), serum glutamic pyruvic transaminase (SGPT), $\gamma$ glutamyl transferase (RGT), and creatinine were not significant among male workers. Female workers in photolithography had abnormal SGPT and RGT of borderline significance, the multivariate adjusted ORs were $9.6195 \% \mathrm{Cl} 0.86$ to 107$)$ and $6.35(95 \% \mathrm{Cl} 0.53$ to 75.8$)$, respectively.

Conclusions: This study suggests that leukopenia is a potential health effect in male fabrication workers of the semiconductor industry. The tasks of the process, maintenance, and equipment engineers which consisted mostly of men put them at risk for intermittent short term peak exposure to glycol ethers, ionising radiation, arsenic, or other toxins. The findings of this medical surveillance are significant; however, a further investigation of the aetiological factors and the subsequent health effects is necessary.
\end{abstract}

T he fabrication process in the semiconductor industry involves exposure of workers to many chemical and physical agents and to ergonomic stressors. Potential toxic agents such as solvents (glycol ethers, xylene, toluene, acetone, isopropyl alcohol, and hexamethyldisizanes) used in the photolithography and cleaning, dopant compounds (arsine, phosphine, and diborane gases) used in diffusion and ion implantation, acids (hydrofluoric and hydrochloric acid) used in etching or cleaning, physical agents (ionisation radiation, radio frequency (RF) radiation, or extremely low frequency-medium frequency (ELF-MF)), and ergonomic stressors such as standing, constrained posture, and repetitive motion. ${ }^{1-6}$ Workers in clean rooms are usually exposed to multiple agents while performing their tasks, and may suffer from potential adverse health effects such as neurological, respiratory, haematological, hepatic, renal, and reproductive problems. ${ }^{1-10}$ The purpose of this study was to assess the risk by conducting liver, kidney, and haematological function tests in a semiconductor plant in Taiwan.

\section{METHODS}

This study is part of a clinical survey conducted on 926 workers from a semiconductor plant in Taiwan in July 1995. The clinical survey included a standard self administered questionnaire. The questions covered demographic data, health status, and symptoms, occupational history including history of jobs with semiconductors and lifestyle variables such as smoking, alcohol consumption, and medication. Chest radiographs, pulmonary function tests, and physical examinations were performed. The results and symptoms of general illness have been published elsewhere. ${ }^{11}$

There were 208 fabrication workers and 718 nonfabrication workers, 19 out of the 208 fabrication workers were excluded because of incomplete tests or questionnaires. Therefore, the study subjects included 185 fabrication workers who were recruited from all available workers in the fabrication section and 47 non-fabrication workers who were randomly sampled from 718 non-fabrication office workers in this factory. Study subjects had complete blood tests-liver function, kidney function, and haematolog. They were classified by working departments as photolithography section, ion implantation section, etching and diffusion section, and office section. Because male fabrication workers worked exclusively as engineers and female fabrication workers worked as operators, sex was considered an important factor and was further stratified in this study.

We excluded one male etching worker, one female photographic worker, and one female office worker from further statistical analyses due to acute infections. We were not able to analyze females implantation workers due to small sample size in that section $(n=2)$. The data from the remaining 227 workers were encoded, entered, and analyzed with the assistance of the statistical analysis system (SAS) PC software package ${ }^{12}$ and database III plus. ${ }^{13}$ We used student's $t$ test and analysis of variance (ANOVA) with Dunnett's multiple comparison procedure to differentiate the differences between the working sections and controls for demographic data, haematology, liver, and renal function tests. Liver function abnormality was defined as serum glutamic oxaloacetic transaminase (SGOT) >34 U/l,

Abbreviations: WBC, white blood cell; SGOT, serum glutamic oxaloacetic transaminase; SGPT, serum glutamic pyruvic transaminase; RGT, $\gamma$ glutamyl transferase; RF radiation, radio frequency radiation; ELF-MF, extremely low frequency-medium frequency; BMI, body mass index; $\mathrm{HBsAg}$, hepatitis B surface antigen status; PEL, permissible exposure limit 


\begin{tabular}{|c|c|c|c|c|c|c|}
\hline Sex and department & Age & $\begin{array}{l}\text { Duration of } \\
\text { fabrication }\end{array}$ & $\begin{array}{l}\text { Body mass } \\
\text { index }\end{array}$ & $\begin{array}{l}\mathrm{HbsAg} \\
\mathrm{n}(\%)\end{array}$ & $\begin{array}{l}\text { Alcohol } \\
\mathrm{n}(\%)\end{array}$ & $\begin{array}{l}\text { Smoker } \\
\mathrm{n}(\%)\end{array}$ \\
\hline \multicolumn{7}{|l|}{ Men: } \\
\hline Photolithography ( $n=20$ ) & $\begin{array}{l}29.1^{* *}(3.5) \\
(24-36)\end{array}$ & $\begin{array}{l}0.87(0.58) \\
(0.04-2.01)\end{array}$ & $\begin{array}{l}23.5(3.1) \\
(18.9-30.8)\end{array}$ & $3(15)$ & $0 *(0)$ & $1 * *(5)$ \\
\hline Implantation $(n=19)$ & $\begin{array}{l}27^{*}(2.7) \\
(23-33)\end{array}$ & $\begin{array}{l}1.28(1.58) \\
(0.04-6)\end{array}$ & $\begin{array}{l}21.5(2.9) \\
(16.8-28.7)\end{array}$ & $2(10.5)$ & $0 *(0)$ & $3(15.8)$ \\
\hline Etching and diffusion $(n=57)$ & $\begin{array}{l}29.1^{*}(3.7) \\
(21-41)\end{array}$ & $\begin{array}{l}1.10(0.73) \\
(0.04-5)\end{array}$ & $\begin{array}{l}23.6(3.5) \\
(17.4-35)\end{array}$ & $9(15.8)$ & $11(19.3)$ & $23(40.4)$ \\
\hline Office $(n=18)$ & $\begin{array}{l}31.2(3.7) \\
(26-36)\end{array}$ & $0.00(0.00)$ & $\begin{array}{l}22.8(2.2) \\
(19.3-27.1)\end{array}$ & $3(16.7)$ & $4(22.2)$ & $5(27.8)$ \\
\hline \multicolumn{7}{|l|}{ Women: } \\
\hline Photolithography ( $n=34$ ) & $\begin{array}{l}25.3^{*}(4.8) \\
(19-37)\end{array}$ & $\begin{array}{l}0.86(0.42) \\
(0.04-2)\end{array}$ & $\begin{array}{l}21.0(3.3) \\
(15.8-29.1)\end{array}$ & $9(26.5)$ & $0(0)$ & $2(5.9)$ \\
\hline Etching and diffusion $(n=50)$ & $\begin{array}{l}4.8^{*}(4.4) \\
(19-39)\end{array}$ & $\begin{array}{l}0.93(0.33) \\
(0.04-2)\end{array}$ & $\begin{array}{l}20.8(2.9) \\
(16-29)\end{array}$ & $7(14)$ & $1(2)$ & $1(2)$ \\
\hline Office $(n=29)$ & $\begin{array}{l}29.8(9.0) \\
(22-54)\end{array}$ & $0.00(0.00)$ & $\begin{array}{l}21.8(3.7) \\
(17.3-33.7)\end{array}$ & $3(10.3)$ & $0(0)$ & $0(0)$ \\
\hline
\end{tabular}

serum glutamic pyruvic transaminase (SGPT) $>36 \mathrm{U} / \mathrm{l}$, and $\gamma$ glutamyl transferase (RGT) $>26 \mathrm{U} / \mathrm{l}$. Renal dysfunction was defined by creatinine test $>1.4 \mathrm{mg} \%$ for men, and $>1.2 \mathrm{mg} \%$ for women. A haematological test with a white blood cell (WBC) count $\leqslant 5 \times 10^{3} / \mathrm{mm}^{3}$, and haemoglobin $<13.5 \mathrm{~g} / \mathrm{dl}$ for men, $<12 \mathrm{~g} / \mathrm{dl}$ for women was regarded as abnormal in this study. The $\chi^{2}$ test or Fischer's exact test were performed to test the differences in the proportions of abnormal blood tests. Logistic regression analyses were applied to calculate smoking, HBsAg, body mass index (BMI), alcohol, and age adjusted odds ratio (OR) of job categories on abnormalities of WBC, SGOT, SGPT, and RGT. Multiple linear regression analyses were used to control the effects of potential confounders on the relation between job categories and numerical outcomes such as values of haematology, kidney, and liver function tests.

\section{RESULTS}

The variables including age, duration of fabrication job, body mass index, hepatitis B surface antigen status (HBsAg), alcohol drinking, and smoking were stratified by sex and presented in table 1. On average, the office workers were significantly older than the fabrication workers. There was a significantly higher prevalence of cigarette smoking and alcohol consumption in male office workers than in male photolithography workers $(p=0.07$ and $p=0.04$, respectively). A significantly higher prevalence of alcohol consumption was found in male controls than in male implantation workers $(p=0.046)$.

Sex specific haematology results are summarised in table 2 . There were significantly lower mean (SD) WBC counts in male photolithography and implantation workers than controls $\left(5870(1190) / \mathrm{mm}^{3} v 7350(1660) / \mathrm{mm}^{3}, \mathrm{p}=0.003 ; 6190(1150) /\right.$

Table 2 Haematology results among workers

\begin{tabular}{|c|c|c|c|c|c|c|c|c|}
\hline Department & $\begin{array}{l}\text { White blood } \\
\text { cells }\left(10^{3}\right)\end{array}$ & $\begin{array}{l}\text { Red blood } \\
\text { cells }\left(10^{5}\right)\end{array}$ & $\begin{array}{l}\text { Haemoglobin } \\
(\mathrm{g} / \mathrm{dl})\end{array}$ & $\begin{array}{l}\text { Packed cell } \\
\text { volume (\%) }\end{array}$ & $\begin{array}{l}\text { Mean } \\
\text { corpuscular } \\
\text { volume (fl) }\end{array}$ & $\begin{array}{l}\text { Mean } \\
\text { corpuscular } \\
\text { haemoglobin } \\
\text { (pg) }\end{array}$ & $\begin{array}{l}\text { Mean } \\
\text { corpuscular } \\
\text { haemoglobin } \\
\text { concentration } \\
\text { (g/dl) }\end{array}$ & $\begin{array}{l}\text { Platelets } \\
\left(10^{4}\right)\end{array}$ \\
\hline \multicolumn{9}{|l|}{ Men: } \\
\hline Photolithography $(n=20)$ & $\begin{array}{l}5.87^{*}(1.19) \\
(4.2-8.4)\end{array}$ & $\begin{array}{l}5.28(0.30) \\
(4.8-5.89)\end{array}$ & $\begin{array}{l}16(0.82) \\
(14.8-17.6)\end{array}$ & $\begin{array}{l}48.4(2.9) \\
(43.7-55.7)\end{array}$ & $\begin{array}{l}91.8(3.4) \\
(86.7-100.2)\end{array}$ & $\begin{array}{l}30.3(1.1) \\
(28.2-32.9)\end{array}$ & $\begin{array}{l}33.0(0.6) \\
(31.6-34.3)\end{array}$ & $\begin{array}{l}23.0(2.8) \\
(17.6-29)\end{array}$ \\
\hline Implantation $(n=19)$ & $\begin{array}{l}6.19 *(1.15) \\
(3.99-7.39)\end{array}$ & $\begin{array}{l}5.28(0.36) \\
(4.68-6.28)\end{array}$ & $\begin{array}{c}15.5(1.13) \\
(12.8-17.3)\end{array}$ & $\begin{array}{l}46.7(2.8) \\
(41-52)\end{array}$ & $\begin{array}{l}88.5(7.5) \\
(65.3-97.9)\end{array}$ & $\begin{array}{l}29.3(2.8) \\
(20.4-31.6)\end{array}$ & $\begin{array}{l}33.1(0.9) \\
(31.2-34.5)\end{array}$ & $\begin{array}{l}22.8(3.7) \\
(17.0-33.8)\end{array}$ \\
\hline Etching and diffusion $(n=57)$ & $\begin{array}{l}6.75(1.51) \\
(3.5-9.8)\end{array}$ & $\begin{array}{l}5.29(0.53) \\
(4.54-7.70)\end{array}$ & $\begin{array}{c}15.6(0.85) \\
(13.7-17.1)\end{array}$ & $\begin{array}{l}47.0(2.2) \\
(41.6-50.8)\end{array}$ & $\begin{array}{l}89.4(6.5) \\
(64.4-99.8)\end{array}$ & $\begin{array}{l}29.7(2.5) \\
(20.3-32.4)\end{array}$ & $\begin{array}{l}33.2(0.9) \\
(29.7-34.4)\end{array}$ & $\begin{array}{l}24.4(4.6) \\
(16.1-36.1)\end{array}$ \\
\hline Office $(n=18)$ & $\begin{array}{l}7.35(1.66) \\
(4.7-10.8)\end{array}$ & $\begin{array}{l}5.21(0.28) \\
(4.68-5.72)\end{array}$ & $\begin{array}{l}15.9(0.86) \\
(14.8-17.4)\end{array}$ & $\begin{array}{l}47.4(2.5) \\
(43.1-51.8)\end{array}$ & $\begin{array}{l}91.1(5.1) \\
(85.1-106.8)\end{array}$ & $\begin{array}{l}30.4(1.5) \\
(28-34.5)\end{array}$ & $\begin{array}{l}33.3(0.6) \\
(32.3-34.2)\end{array}$ & $\begin{array}{l}24.2(3.9) \\
(16.7-33.1)\end{array}$ \\
\hline \multicolumn{9}{|l|}{ Women: } \\
\hline Photolithography $(n=34)$ & $\begin{array}{l}6.90(1.47) \\
(4.3-10.9)\end{array}$ & $\begin{array}{l}4.69(0.53) \\
(3.82-6.07)\end{array}$ & $\begin{array}{l}13.4(0.95) \\
(11-15.1)\end{array}$ & $\begin{array}{l}41.5(2.8) \\
(34.9-46.5)\end{array}$ & $\begin{array}{l}89.3(9.1) \\
(64.1-101.2)\end{array}$ & $\begin{array}{l}28.9(3.4) \\
(20.1-33.4)\end{array}$ & $\begin{array}{l}31.8(3.4) \\
(13-34.2)\end{array}$ & $\begin{array}{l}27.7(7.1) \\
(17.2-47.9)\end{array}$ \\
\hline Etching and diffusion $(n=50)$ & $\begin{array}{l}7.27(1.73) \\
(4.5-10.2)\end{array}$ & $\begin{array}{l}4.61(0.40) \\
(3.57-6.10)\end{array}$ & $\begin{array}{l}13.4(1.0) \\
(11.1-15.3)\end{array}$ & $\begin{array}{l}41.2(2.9) \\
(33.9-46.6)\end{array}$ & $\begin{array}{l}89.5(6.2) \\
(64.2-102)\end{array}$ & $\begin{array}{l}29.2(2.3) \\
(19.9-33.1)\end{array}$ & $\begin{array}{l}32.6(0.7) \\
(30.7-34)\end{array}$ & $\begin{array}{l}27.0(6.8) \\
(14.6-46.4)\end{array}$ \\
\hline Office $(n=29)$ & $\begin{array}{l}7.03(1.83) \\
(4.22-10.9)\end{array}$ & $\begin{array}{l}4.68(0.33) \\
(4.06-5.43)\end{array}$ & $\begin{array}{l}13.6(0.84) \\
(11.4-15.1)\end{array}$ & $\begin{array}{l}41.8(2.6) \\
(35.2-45.9)\end{array}$ & $\begin{array}{l}89.7(6.6) \\
(67.3-98.1)\end{array}$ & $\begin{array}{l}29.3(2.1) \\
(22.5-32.6)\end{array}$ & $\begin{array}{l}32.6(0.7) \\
(31.6-34.4)\end{array}$ & $\begin{array}{l}24.7(4.7) \\
(13-35.6)\end{array}$ \\
\hline
\end{tabular}

*Significance performed by multiple comparison of Dunnett's procedure with office workers as reference group. Data are mean (SD) (range). 


\begin{tabular}{|c|c|c|c|c|}
\hline Department & SGOT (U/I) & SGPT (U/I) & RGT (U/I) & Creatinine (mg\%) \\
\hline \multicolumn{5}{|l|}{ Men: } \\
\hline Photolithography $(n=20)$ & $\begin{array}{l}20.8(5.0) \\
(14-35)\end{array}$ & $\begin{array}{l}26.0(16.5) \\
(8-76)\end{array}$ & $\begin{array}{l}16.9(10.4) \\
(8-53)\end{array}$ & $\begin{array}{l}1.08(0.25) \\
(0.9-2)\end{array}$ \\
\hline Implantation $(n=19)$ & $\begin{array}{l}20.1(5.1) \\
(11-32)\end{array}$ & $\begin{array}{l}18.6(11.0) \\
(7-49)\end{array}$ & $\begin{array}{l}15.5(15.1) \\
(7-74)\end{array}$ & $\begin{array}{l}1.01(0.09) \\
(0.9-1.2)\end{array}$ \\
\hline Etching and diffusion $(n=57)$ & $\begin{array}{l}22.4(7.8) \\
(14-50)\end{array}$ & $\begin{array}{l}28.3(19.0) \\
(8-127)\end{array}$ & $\begin{array}{l}15.6(8.5) \\
(7-47)\end{array}$ & $\begin{array}{l}1.04(0.13) \\
(0.7-1.5)\end{array}$ \\
\hline Office $(n=18)$ & $\begin{array}{l}22.6(10.1) \\
(14-54)\end{array}$ & $\begin{array}{l}22.4(14.0) \\
(7-56)\end{array}$ & $\begin{array}{l}18.7(15.0) \\
(8-71)\end{array}$ & $\begin{array}{l}1.01(0.13) \\
(0.8-1.3)\end{array}$ \\
\hline \multicolumn{5}{|l|}{ Women: } \\
\hline Photolithography ( $n=34)$ & $\begin{array}{l}22.7(19.4) \\
(12-127)\end{array}$ & $\begin{array}{l}25.8(49.2) \\
(5-295)\end{array}$ & $\begin{array}{l}15.3(25.0) \\
(4-133)\end{array}$ & $\begin{array}{l}0.75(0.11) \\
(0.5-0.9)\end{array}$ \\
\hline Etching and diffusion $(n=50)$ & $\begin{array}{l}23.6(34.8) \\
(13-261)\end{array}$ & $\begin{array}{l}25.2(66.5) \\
(6-480)\end{array}$ & $\begin{array}{l}10.7(8.6) \\
(3-62)\end{array}$ & $\begin{array}{l}0.76(0.10) \\
(0.6-1.1)\end{array}$ \\
\hline Office (n=29) & $\begin{array}{l}19.5(7.1) \\
(12-51)\end{array}$ & $\begin{array}{l}16.0(16.0) \\
(6-93)\end{array}$ & $\begin{array}{l}10.0(3.8) \\
(6-24)\end{array}$ & $\begin{array}{l}0.77(0.16) \\
(0.1-0.9)\end{array}$ \\
\hline
\end{tabular}

$\mathrm{mm}^{3}$ v $7350(1660) / \mathrm{mm}^{3}, \mathrm{p}=0.018$; respectively). The liver and kidney function tests showed no significant difference among workers in different job categories (table 3). From table 4, a similar result was found in multiple regression analysis, WBC counts had significantly inverse associations with the job of photolithographer $(p=0.0026)$, implantation $(p=0.064)$, and etching or diffusion $(p=0.068)$ after adjusting for smoking, body mass index, age, and other job variables. There was a sig- nificantly positive association between WBC counts and BMI $(\mathrm{p}=0.006)$.

There was a higher prevalence of decreased WBC counts in male photolithography workers $(6$ of $20 ; 30 \%$ ) than in male controls ( 1 of $18 ; 5.6 \%$ ). The crude OR was $7.3(95 \%$ confidence interval (95\% CI) 0.96 to 55.6$)$ and the OR adjusted for smoking, BMI, and age was 8.1 (95\% CI 0.83 to 78.3 ). There was a higher non-significant prevalence of decreased WBC

Table 4 Multiple linear regression analyses between white blood cells (WBCs), liver function (SGOT, SGPT, and RGT), and renal function tests (creatinine) among male workers

\begin{tabular}{|c|c|c|c|c|c|}
\hline Indicators & White blood cells & SGOT & SGPT & RGT & Creatinine \\
\hline Intercept & $\begin{array}{l}4.38(1.03)^{*} \\
(0.0001)^{*}\end{array}$ & $\begin{array}{l}3.9(5.26) \\
(0.46)\end{array}$ & $\begin{array}{l}-34.5(11.5) \\
(0.0033)\end{array}$ & $\begin{array}{l}-15.8(7.72) \\
(0.043)\end{array}$ & $\begin{array}{l}0.74(0.12) \\
(0.0001)\end{array}$ \\
\hline $\begin{array}{l}\text { Smoking: } \\
\quad 1 \text { (Smoker) } \\
0 \text { (Non-smoker) }\end{array}$ & $\begin{array}{l}0.44(0.31) \\
(0.16)\end{array}$ & $\begin{array}{l}-0.75(1.74) \\
(0.67)\end{array}$ & $\begin{array}{l}-0.62(3.78) \\
(0.87)\end{array}$ & $\begin{array}{l}-1.63(2.55) \\
(0.52)\end{array}$ & $\begin{array}{l}0.007(0.038) \\
(0.85)\end{array}$ \\
\hline $\begin{array}{l}\text { Hbs Ag: } \\
\quad 1 \text { (Positive) } \\
0 \text { (Negative) }\end{array}$ & & $\begin{array}{l}5.56(1.89) \\
(0.0041)\end{array}$ & $\begin{array}{l}8.44(4.13) \\
(0.043)\end{array}$ & $\begin{array}{l}7.86(2.78) \\
(0.0056)\end{array}$ & \\
\hline BMI (Each increment) & $\begin{array}{l}0.118(0.042) \\
(0.006)\end{array}$ & $\begin{array}{l}0.78(0.22) \\
(0.0005)\end{array}$ & $\begin{array}{l}2.43(0.47) \\
(0.0001)\end{array}$ & $\begin{array}{l}1.41(0.32) \\
(0.0001)\end{array}$ & $\begin{array}{l}0.012(0.0047) \\
(0.01)\end{array}$ \\
\hline $\begin{array}{l}\text { Alcohol: } \\
1 \text { (Drinker) } \\
0 \text { (Non-drinker) }\end{array}$ & & $\begin{array}{l}-1.41(2.37) \\
(0.55)\end{array}$ & $\begin{array}{l}-2.73(5.16) \\
(0.60)\end{array}$ & $\begin{array}{l}3.42(3.48) \\
(0.33)\end{array}$ & $\begin{array}{l}0.01(0.052) \\
(0.85)\end{array}$ \\
\hline $\begin{array}{l}\text { Age: } \\
\quad 1(\geqslant 30) \\
0(<30)\end{array}$ & $\begin{array}{l}0.28(0.27) \\
(0.31)\end{array}$ & $\begin{array}{l}1.04(1.4) \\
(0.46)\end{array}$ & $\begin{array}{l}1.74(3.06) \\
(0.57)\end{array}$ & $\begin{array}{l}1.33(2.06) \\
(0.52)\end{array}$ & $\begin{array}{l}-0.028(0.031) \\
(0.37)\end{array}$ \\
\hline $\begin{array}{l}\text { Job categories (office wo } \\
\text { Photolithography }\end{array}$ & $\begin{array}{l}\text { eference group): } \\
-1.41(0.46) \\
(0.0026)\end{array}$ & $\begin{array}{l}-2.57(2.33) \\
(0.27)\end{array}$ & $\begin{array}{l}1.66(5.07) \\
(0.74)\end{array}$ & $\begin{array}{l}-1.98(3.41) \\
(0.56)\end{array}$ & $\begin{array}{l}0.058(0.051) \\
(0.26)\end{array}$ \\
\hline Implantation & $\begin{array}{l}-0.87(0.47) \\
(0.064)\end{array}$ & $\begin{array}{l}-1.26(2.37) \\
(0.6)\end{array}$ & $\begin{array}{l}-0.23(5.17) \\
(0.97)\end{array}$ & $\begin{array}{l}-0.27(3.48) \\
(0.94)\end{array}$ & $\begin{array}{l}0.01(0.052) \\
(0.85)\end{array}$ \\
\hline Etching and diffusion & $\begin{array}{l}-0.70(0.38) \\
(0.068)\end{array}$ & $\begin{array}{l}-0.55(1.93) \\
(0.78)\end{array}$ & $\begin{array}{l}4.3(4.2) \\
(0.31)\end{array}$ & $\begin{array}{l}-3.59(2.83) \\
(0.21)\end{array}$ & $\begin{array}{l}0.013(0.04) \\
(0.76)\end{array}$ \\
\hline$R^{2}$ & $\begin{array}{l}0.19 \\
(0.0009)\end{array}$ & $\begin{array}{l}0.17 \\
(0.0085)\end{array}$ & $\begin{array}{l}0.25 \\
(0.0001)\end{array}$ & $\begin{array}{l}0.23 \\
(0.0005)\end{array}$ & $\begin{array}{l}0.094 \\
(0.22)\end{array}$ \\
\hline
\end{tabular}




\begin{tabular}{|c|c|c|c|c|}
\hline Sex/department & White blood cells & SGOT & SGPT & RGT \\
\hline \multicolumn{5}{|l|}{ Men: } \\
\hline Photolithography $(n=20)(n(\%))$ & $6(30)$ & $1(5)$ & $3(15)$ & $2(10)$ \\
\hline OR $(95 \% \mathrm{Cl}) \dagger$ & $7.3^{* *}(0.96$ to 55.6$)$ & $0.4(0.01$ to 6.9$)$ & $0.9(0.12$ to 6.7$)$ & $0.4(0.04$ to 3.1$)$ \\
\hline AOR $(95 \%$ CI) & $8.1^{* *}(0.83$ to 78.3$)$ & $0.4(0.02$ to 5.8$)$ & $0.8(0.11$ to 5.1$)$ & $0.4(0.05$ to 3.74$)$ \\
\hline Implantation (n=19) (n (\%)) & $4(21.1)$ & $0(0)$ & $2(10.5)$ & $1(5.3)$ \\
\hline OR $(95 \%$ CI) & 4.5 (0.5 to 45.2$)$ & & $0.6(0.06$ to 5.3$)$ & $0.2(0.01$ to 2.3$)$ \\
\hline AOR $(95 \% \mathrm{Cl})$ & $3.7(0.36$ to 39.3$)$ & & $0.9(0.11$ to 7.1$)$ & $0.4(0.03$ to 5.7$)$ \\
\hline Etching and diffusion $(n=57)(n(\%))$ & $8(14)$ & $4(7.0)$ & $12(21.1)$ & $5(8.8)$ \\
\hline OR $(95 \% \mathrm{CI})$ & $2.8(0.32$ to 23.9$)$ & $0.6(0.08$ to 5.3$)$ & $1.3(0.3$ to 6.9$)$ & $0.3(0.07$ to 1.8$)$ \\
\hline AOR $(95 \%$ CI) & $3.3(0.37$ to 28.8$)$ & $0.6(0.08$ to 13.1$)$ & $1.2(0.3$ to 5.3$)$ & $0.3(0.05$ to 1.65$)$ \\
\hline Office $(n=18)(n(\%))$ & $1(5.6)$ & $2(11.1)$ & $3(16.7)$ & $4(22.2)$ \\
\hline OR $(95 \% \mathrm{CI})$ & 1.0 & 1.0 & 1.0 & 1.0 \\
\hline AOR $(95 \% \mathrm{Cl})$ & 1.0 & 1.0 & 1.0 & 1.0 \\
\hline \multicolumn{5}{|l|}{ Women: } \\
\hline Photolithography (n=34) (n (\%)) & $4(11.8)$ & $2(5.9)$ & $6(17.7)$ & $2(5.9)$ \\
\hline OR $(95 \%$ CI) & $0.8(0.2$ to 3.7$)$ & $1.8(0.1$ to 51.7$)$ & $6.0^{* *}(0.63$ to 141$)$ & $4.5(0.21$ to 98.5$)$ \\
\hline AOR $(95 \% \mathrm{Cl})$ & 0.5 (0.1 to 2.44 ) & $2.4(0.16$ to 34$)$ & $9.6 * *(0.86$ to 107$)$ & $6.4^{* *}(0.53$ to 75.8$)$ \\
\hline Etching and diffusion $(n=50)(n(\%))$ & $6(12)$ & $4(8)$ & $4(8)$ & $2(4)$ \\
\hline OR $(95 \% \mathrm{CI})$ & $0.9(0.22$ to 3.3$)$ & $2.4(0.23$ to 60.2$)$ & $2.4(0.23$ to 60.2$)$ & $3.0(0.14$ to 65.6$)$ \\
\hline AOR $(95 \%$ CI) & $0.6(0.15$ to 2.5$)$ & $4.2(0.36$ to 48.4$)$ & $4.6(0.4$ to 51.9$)$ & $3.3(0.26$ to 43.1$)$ \\
\hline Office (n=29) (n (\%)) & $4(13.8)$ & $1(3.5)$ & $1(3.5)$ & $0(0)$ \\
\hline OR $(95 \% \mathrm{CI})$ & 1.0 & 1.0 & 1.0 & 1.0 \\
\hline AOR $(95 \%$ CI) & 1.0 & 1.0 & 1.0 & 1.0 \\
\hline
\end{tabular}

${ }^{*} \mathrm{p}<0.05 ;{ }^{*} \mathrm{p}<0.1 ; \uparrow \mathrm{TR}=$ crude odds ratio; $\mathrm{AOR}=$ odds ratio adjusted by age, cigarette smoking, alcohol drinking, hepatitis $B$ surface antigen, and body mass index.

counts for male implanters $(21.1 \%)$ and etching or diffusion workers (14\%) than that of office workers $(5.6 \%)$ (table 5$)$.

The comparisons among female workers were only of borderline significance. A higher prevalence of abnormal SGPT was found in female photolithography workers (6 of 34; $17.7 \% ; \mathrm{p}=0.08$ ) than in female control workers ( 1 of $29 ; 3.5 \%$ ), the crude OR was 6.0 (95\% CI, 0.63 to 141$)$ and the OR adjusted for HBsAg, BMI, and age was 9.6 (95\% CI, 0.86 to 107). There was a non-significant potentially higher prevalence of abnormal SGPT in female etching or diffusion workers than in female office workers (table 5).

The results suggested that work as a a male photolithography worker or an etching or diffusion worker was associated with health problems of low WBCs, however, being a female fabrication worker was potentially linked with problems of liver dysfunction.

\section{DISCUSSION}

Workers in clean rooms are usually exposed to multiple agents while performing their tasks, and may have from potential adverse health effects. ${ }^{1-10}$ Glycol ethers, arsenic, and ionising radiation have been reported to have haematological toxicity. ${ }^{15}$ Ethylene glycol monomethyl ether and other glycol ethers have been reported to cause cytopenia and hypoplastic bone marrow in lithographers, with relatively low exposure (concentration range from $0.6 \mathrm{ppm}$ to $6.43 \mathrm{ppm}) .{ }^{14}$ Ionising radiation and arsenic (organic and inorganic) are also documented causes of aplastic anaemia and depression of bone marrow function. ${ }^{15}$ Solvents with hepatic toxicity including glycols, tetrachloroethylene, and aromatic hydrocarbons are commonly used in the semiconductor process. ${ }^{6}$ In this study, male workers in the photolithography and implantation sections had significantly lower average WBC counts than did workers in the office areas. This difference was still held after adjusting for possible confounding factors. The results suggest that haematological abnormalities are potential problems among male fabrication workers in the semiconductor industry.
Through walk through surveys, we found that careful attention was paid to control of toxic gases and chemicals used in this plant. There were air tight clean rooms where air was continuously filtered and recirculated to remove particles facilitated by central gas detecting systems with an alarm, and clean room garments in this semiconductor factory. A major goal of these semiconductor factories is to prevent catastrophic toxic chemical spills and fires or explosions. Another goal of the clean room design is to protect the semiconductor chip, which is sensitive to low levels of air particulate contaminants. The production process was automatic so that workers have no direct contact with the hazard under normal conditions, and exhaust ventilation was provided at the source of emission to carry away airborne chemicals before the employee can breathe them. Most surveys on chemical contaminant concentrations in wafer manufacturing clean rooms in western countries have shown concentrations well under $1 \mathrm{ppm}$ and usually undetectable for the most widely used chemicals. ${ }^{16}$ Previous surveys of four semiconductor plants by Institute of Occupatoinal Safety and Health in Taiwan had similar results. ${ }^{17}$ The concentration of acetone ranged from 0.03 to $1.51 \mathrm{ppm}$, isopropyl alcohol from 0.01 to $0.69 \mathrm{ppm}, n$-butyl acetate from 0.01 to $0.35 \mathrm{ppm}$, xylene from 0.01 to $3.2 \mathrm{ppm}$, and 2-ethoxyethyl acetate from 0.16 to 0.33 $\mathrm{ppm}$. The estimated exposure concentrations of solvents were all below the Taiwanese permissible exposure limit (PEL) of $100 \mathrm{ppm}$. These findings suggested that the adverse health effects noted might have occurred in fabrication workers with exposures below the PEL, and that the current PEL might not be low enough to protect workers from toxic hazards.

Technology now exists to control exposures associated with routine production operations to well below the PELs. When these control systems work as expected, maintenance workers will generally be the only employees with a notable risk of higher exposures. The tasks of male processors, maintenance workers, and equipment engineers may put them at risk of intermittent short term peak exposure to glycol ethers for 
photolithography workers or ionising radiation and arsenic for implantation workers. Other toxins which may cause decreased WBC counts may also be present. The job categories included cleaning up chemical spills and leaks, cleaning equipment, mixing the chemical, changing solid sources and pump oil, doing preventive maintenance on a machine, doing an emergency response for a machine, and changing or filling containers for chemicals on machines. Male engineers usually wore cotton masks instead of cartridge or air masks during the operation. Lack of adequate respiratory protection may allow workers to be exposed to haematological toxins. One previous report indicated that engineers might be exposed to high concentration of toxic chemicals during preventive maintenance on dry etching machines. ${ }^{18}$ Recently, a survey on Taiwan semiconductor factories showed that peak concentration of hydrogen chloride leakage (in less than 15 minutes) was up to 90 ppm which was far above the short term exposure limit (STEL) of $5 \mathrm{ppm}$. The same situation occurred during preventive maintenance on an etching machine for hydrogen cyanide with concentrations up to $60 \mathrm{ppm}$, which was also far above the STEL of 10 ppm..$^{19}$ Another recent report on Taiwan semiconductor industries has also shown that most of airborne chemicals were below ppm concentrations during normal operations in the clean room. ${ }^{20}$ Routine maintenance of tools might result in higher (above the PEL) concentrations of the total hydrocarbons, hydrogen cyanide, chlorocyanide for some metal etchers, and higher concentration ( $>1 \mathrm{ppm})$ of benzene, toluene, xylene, chloroform, and tetrachloromethane were found in PE-CVD and oxide etchers. ${ }^{20}$

Female photolithography workers had a higher prevalence, of borderline significance, of abnormal SGPT than did workers in the office areas after adjusting for possible confounding factors. This result suggested that hepatic abnormalities could occur in female fabrication workers in the semiconductor industry. Their jobs included machine operation and loading or removing boats of wafer. Potential multichemical exposures from daily operations and recycled air ventilation in fabrication environments were important issues that awaited further investigation.

Also, liver function tests (SGOT, SGPT, and RGT) were significantly related to HBsAg and BMI after adjusting for smoking, age, alcohol consumption, and job variables. These findings were consistent with other reports in which body mass index and hepatitis were strongly associated with increased liver enzyme activity. ${ }^{21-23}$ Our data have also shown significant association between WBC counts and BMI, which is consistent with previous reports. ${ }^{24} 25$

Most studies in the semiconductor industry reported increased risk of spontaneous abortion among workers in fabrication rooms. ${ }^{89}$ Also, our previous study has suggested that restrictive lung abnormality was a potential health effect in male fabrication workers. ${ }^{11}$ Nevertheless, less has been reported about other possible health effects from toxic exposures during the fabrication process. The current study is limited by its cross sectional design, because exposure conditions in such industries are relatively constant due to ventilation controls. The results of subchronic effects show that the tasks of fabrication workers may put them at risk of developing long term haematological and hepatic abnormalities. A causal inference from the findings cannot be made by this cross sectional study due to temporal problems, and longitudinal studies are required to assess causality from our results. The current findings also suggest that further studies are necessary to identify the specific agents which could cause haematological and hepatic damage in fabrication workers. The results of this medical surveillance give ideas for further investigation of possible aetiological factors and the subsequent health effects in high technological industries.

\section{ACKNOWLEDGEMENTS}

This study was supported by grants from the National Science Council (NSC85-2331-B182-106, NSC86-2314-B182-114) and Chang Gung research fund (CMRP599, CMRP1210) of Taiwan. We thank Ms Chuen-Jiuan Wong for research assistance and Dr Paul Brandt-Rauf for his thoughtful comments. We are also indebted to the workers of the semiconductor company who participated in this study.

\section{Authors' affiliations}

J-C J Luo, L L Hsieh, M J W Chang, Department of Public Health, Chang Gung University, 259 Wen-Hwa 1st Road, Kwei-Shan, Tao-Yuan, Taiwan

J-C J Luo, Department of Family Medicine, Chang Gung Memorial Hospital, Tao-Yuan, Taiwan

K-H Hsu, Laboratory for Epidemiology, Department of Health Care Management, Chang Gung University, Tao-Yuan, Taiwan

\section{REFERENCES}

1 Wald PH, Jones JR. Semiconductor manufacturing: an introduction to processes and hazards. Am J Ind Med 1987:11:203-21.

2 Harrison M. Semiconductor manufacturing hazards. In: Sullivan JB, Krieger GR, eds. Hazardous materials toxicology: clinical principles of environmental health. Baltimore: Williams and Wilkins; 1992:472-504.

3 Wald PH, Becker CE. Toxic gases used in the microelectronics industry. In: Ladou J, ed. The microelectronics industry. State of the art reviews. Philadelphia: Hanley and Belfus, 1986:105-17.

4 Lewis DR. Dopant materials used in the microelectronics industry. In Ladou J, ed. The microelectronics industry. State of the art reviews. Philadelphia: Hanley and belfus, Inc; 1986:35-47.

5 Teitlebaum DT. Photoactive chemicals used in photoresist systems. In: Ladou J, ed. The Microelectronics Industry. State of The Art Reviews. Philadelphia: Hanley and Belfus, 1986:59-68

6 Cone JE. Health hazards of solvents. In: Ladou J, ed. The microelectronics industry. State of the art reviews. Philadelphia: Hanley and Belfus, 1986:69-87.

7 Schenker M. Occupational lung diseases in the industrializing and industrialized world due to modern industries and modern pollutants. Tuber Lung Dis 1992;73:27-32.

8 Pastides H, Calabrese EJ, Hosmer DW, et al. Spontaneous abortion and general illness symptoms among semiconductor manufacturers. J Occup Med 1988;30:543-51

9 Swan SH, Beaumont JJ, Hammond K, et al. Historical cohort study of spontaneous abortion among fabrication workers in the semiconductor health study: agent-level analysis. Am J Ind Med 1995; 28:751-69.

10 Cohr KH, Stokholm J. Toluene, a toxicologic review. Scand J Work Environ Health 1979;5:71-90.

11 Luo J-C J, Hsu K-H, Hsieh L-L, et al. Lung function and general illness symptoms in a semiconductor manufacturing facility. J Occup Environ Med 1998;40:895-900.

12 SAS Institute. SAS procedure guide, release 6.11. Cary, NC: SAS Institute, 1995.

13 Database III plus. Torrance, CA: Ashton-Tate, 1986.

14 Cullen MR, Rado T, Waldron JA, et al. Bone marrow injury in lithographers exposed to glycol ethers and organic solvents used in multicolor offset and ultraviolet curing printing processes. Arch Environ Health 1983;38:347-54.

15 Aplastic anemia. In: Weeks JL, Levy BS, Wagner GR, eds. Preventing occupational diseases and injury. Washington, DC: American Public Health Association, 1991:105-9.

16 Scarpace L, Williams $M$, Baldwin D, et al. Results of industrial hygiene sampling in semiconductor manufacturing operations. In: American Conference of Government Industrial Hygienists, ed. Hazard assessment and control technology in semiconductor manufacturing. Chelsea, MI: Lewis, 1989:47-52.

17 Shih HC, Kosim Y, Yu JP. Analytical method for workplace airborne organics in semiconductor photolithographic processes. Occup Health Saf 1996;4:2:111-22.

18 Strang CR, Levine SP, Herget WF. A preliminary evaluation of the Fourier transform infrared spectrometer as a quantitative air monitor for semiconductor manufaturing process emissions. Am Ind Hyg Assoc J 1989: 50:2:70-7

19 Chang CP, Song LY, Chu CQ, et al. The evaluation of hazardous gases emission from the preventive maintenance procedure in semiconductor factory. Journal of IOSH Occupational Safety and Health 20008:205-16.

20 Yeh MP, Wu RT, Yu JP. Probing airborne chemicals of semiconductor workplace using gas chromatography mass spectrometry. Journal of IOSH Occupational Safety and Health 2000;8: 159-94.

21 Reichling JJ, Kaplan MM. Clinical use of serum enzymes in liver diseases. Dig Dis Sci 1988;33:1601-4.

22 Salvaggio A, Periti M, Miano L, et al. Body mass index and liver enzyme activity in serum. Clin Chem 1991;37:720-3.

23 Burns CJ, Boswell JW, Olsen GW. Liver enzyme activity and body mass index. J Occup Environ Med 1997:38:1248-52.

24 Petitti DB, Kipp H. The leukocyte count: associations with intensity of smoking and persistence of effect after quitting. Am J Epidemiol 1986; 123:89-95

25 Nieto FJ, Szklo M, Folsom AR, et al. Leukocyte count correlatres in middle-aged adults: the atherosclerosis risk in communities (ARIC) study. Am J Epidemiol 1992;136:525-37. 